\title{
Resistance of Neisseria gonorrhoeae to antimicrobial hydrophobic agents is modulated by the mtrRCDE efflux system
}

\author{
Kayla E. Hagman, ${ }^{1}$ Wubin Pan, ${ }^{2}$ Brian G. Spratt, ${ }^{2}$ Jacqueline T. Balthazar, \\ Ralph C. Judd ${ }^{3}$ and William M. Shafer ${ }^{1,4}$
}

Author for correspondence: William M. Shafer. Tel: +1 404728 7688. Fax: +1 4043292210.

e-mail: wshafer@unix.cc.emory.edu

1 Department of
Microbiology and
Immunology, Emory
University School of
Medicine, Atlanta,
GA 30322, USA
2 Microbial Genetics Group,
School of Biological
Sciences, University of
Sussex, Falmer, Brighton
BN1 9QG, UK
3 Division of Biological
Sciences, University of
Montana, Missoula,
MT 59812-1002, USA
4 Laboratories of Microbial
Pathogenesis, Medical
Research Service, VA
Medical Center (Atlanta),
Decatur, GA 30033, USA

\begin{abstract}
The $m$ tr (multiple transferable resistance) system of Neisseria gonorrhoeae determines levels of gonococcal resistance to hydrophobic agents (HAs), including detergent-like fatty acids and bile salts that bathe certain mucosal surfaces. The genetic organization of the mtr system was determined and found to consist of the $m$ trR gene, which encodes a transcriptional regulator (MtrR), and three tandemly linked genes termed mtrCDE. The mtrCDE genes were organized in the same apparent transcriptional unit, upstream and divergent from the $m$ trR gene. The $m$ trCDE-encoded proteins of $N$. gonorrhoeae were analogous to a family of bacterial efflux/transport proteins, notably the MexABOprK proteins of Pseudomonas aeruginosa and the AcrAE and EnvCD proteins of Escherichia coli, that mediate resistance to drugs, dyes, and detergents. Inactivation of the mtrC gene resulted in loss of the MtrC lipoprotein and rendered gonococci hypersusceptible to structurally diverse HAs; this revealed the importance of the mtr system in determining HA $^{\mathrm{R}}$ in gonococci. Further support for a role of the mtrCDE gene complex in determining levels of $H^{R}$ in gonococci was evident when transformants bearing mutations in the $m$ trR gene were analysed. In this respect, missense and null mutations in the mtrR gene were found to result in increased levels of MtrC and HAR. However, high levels of MtrC and HAR, similar to those observed for clinical isolates, were associated with a single bp deletion in a 13 bp inverted repeat sequence that intervened the divergent $m$ trR and $m t r C$ genes. We propose that the $13 \mathrm{bp}$ inverted-repeat sequence represents a transcriptional control element that regulates expression of the mtrRCDE gene complex, thereby modulating levels of gonococcal susceptibility to HAs.
\end{abstract}

Keywords: antibiotic resistance, efflux, gonococci, membrane proteins, regulation

\section{INTRODUCTION}

The capacity of Neisseria gonorrboeae to resist the toxic action of faecal lipids and bile salts is likely required for gonococci to survive at certain mucosal surfaces (Shafer et al., 1984). Strains resistant to multiple, structurally diverse antimicrobial hydrophobic agents (HAs) are frequently isolated from homosexual males with rectal

Abbreviations: $\mathrm{CBB}$, Coomassie Brilliant Blue; HA, hydrophobic agents; IEF, isoelectric focusing; mAb, monoclonal antibody; MFP, membrane fusion protein.

The $m t r C$ nucleotide sequence has been assigned the GenBank accession number U14993. infections (Morse et al., 1982), presumably because toxic faecal lipids provide strong selective pressure for mutations that serve to enhance gonococcal $\mathrm{HA}^{\mathbf{R}}$. The molecular mechanism(s) responsible for gonococcal $\mathrm{HA}^{\mathbf{R}}$ is unclear, although the $m$ tr system has been implicated (Sparling et al., 1978). In this respect, a report from over a decade ago (Morse et al., 1982) estimated that $12.5 \%$ of patients with gonococcal disease are infected with strains that are $\mathrm{HA}^{\mathbf{R}}$ due to the $m$ tr system.

Although the gonococcal $m$ tr system has been known for over 20 years (Maness \& Sparling, 1973), it was not until recently (Pan \& Spratt, 1994) that a mutation having the capacity to confer $\mathrm{HA}^{\mathbf{R}}$ upon a highly sensitive strain (FA19) was identified. This mutation was shown to occur 
in the $m t r R$ gene, which encodes a 210 amino acid protein bearing significant similarity to numerous repressors of transcription (summarized by Pan \& Spratt, 1994), particularly those of the tetracycline repressor family (Brow et al., 1985), and the LuxR transcriptional-activator protein (Schwartzman et al., 1992). The MtrR protein from strain FA19 differed from that possessed by two $\mathrm{HA}^{\mathrm{R}}$ clinical isolates by only a single amino acid, which was outside the proposed DNA-binding domain of the MtrR protein. Accordingly, $\mathrm{HA}^{\mathbf{R}}$ in gonococci was postulated to be due to a reduction of MtrR repressor activity, which resulted in enhanced expression of other gene(s) that mediate resistance. This hypothesis was consistent with earlier studies (Guymon et al., 1978) that showed elevated levels of a membrane protein, particularly a lipoprotein termed the Mtr-associated protein (Chen et al., 1985), in an $\mathrm{HA}^{\mathrm{R}}$ transformant of strain FA19.

Subsequent cloning of the gene for the Mtr-associated protein, $m \operatorname{tr} C$, which encodes a $44 \mathrm{kDa}$ membrane lipoprotein described herein, revealed its close proximity to the $m t r R$ gene. Divergently transcribed from $m t r R, m t r C$ mapped $250 \mathrm{bp}$ upstream of the regulatory gene and was considered a candidate for regulation by MtrR (Pan \& Spratt, 1994). The predicted amino acid sequence for MtrC indicated that it was highly similar to two Escherichia coli membrane lipoproteins termed AcrA (Ma et al., 1993) and EnvC (Klein et al., 1991), and MexA of Pseudomonas aeruginosa (Poole et al., 1993b). These proteins, together with AcrE, EnvD and MexB (along with OprK), are known to be important in determining levels of bacterial resistance to multiple antibiotics (Poole et al., 1993b) and acridine dyes (Ma et al., 1993) by an efflux-based mechanism (Nikaido, 1994). The levels of AcrAE and EnvCD in E. coli may be controlled by their respective regulatory proteins, AcrR and EnvR (Pan \& Spratt, 1994), which are analogous to the MtrR protein of the gonococcus.

Our goal in this study was to determine the relationship between the gonococcal mtr system and other bacterial systems (Nikaido, 1994) that mediate resistance to structurally diverse antimicrobial agents. We now report the complete amino acid sequence for the $\mathrm{MtrC}$ lipoprotein and show that it is encoded within a four-gene complex, the $m \operatorname{trRCDE}$ system, that mediates $\mathrm{HA}^{\mathrm{R}}$ in gonococci. The mtrRCDE region of the gonococcal chromosome encodes four distinct proteins sharing homology to the products of three bacterial operons, acr $\mathrm{R} A E$ and env $\mathrm{R} C D$ of $E$. coli and mex $A B o p r K$ of $P$. aeruginosa, involved in mediating resistance to structurally diverse antimicrobial agents by an efflux-based mechanism. Based on these similarities, we propose that the capacity of gonococci to resist the antimicrobial action of structurally diverse hydrophobic compounds, including fatty acids and bile salts that bathe mucosal surfaces, is due to an efflux-based system mediated by the MtrCDE proteins.

\section{METHODS}

Bacterial strains. The $N$. gonorrboeae strains used in this study are described in Table 1. Strains FA19, FA171 and BR87 were kindly provided by P.F. Sparling (University of North
Carolina, Chapel Hill, NC, USA). Strains FA171 and BR87 were constructed in the early 1970s (Sarubbi et al., 1975; Sparling $e t$ al., 1975) by transformation and require special comment since they are now known to contain different mutations that can transform strain FA19 for different levels of $\mathrm{HA}^{\mathrm{R}}$ (Table 1). In constructing strain FA171, donor DNA from strain FA48 (as FA19 but $m$ trR-2 and penB2) was used to transform strain FA19 for $\mathrm{HA}^{\mathrm{R}}$. The construction of strain BR87 involved the introduction of DNA from strain FA47 (as FA19 but env-2 str7 pen A2) into strain FA140 (as FA19 but pen $A 2$ mtrR-171 penB2). Strain BR87, however, contains a phenotypically suppressed mutation in its $m t r R$ gene, due to the presence of an unlinked mutation in the env-2 locus (Sarubbi et al., 1975), and it displays increased susceptibility to HAs (Table 1); phenotypic suppression of the mtrR gene in strain BR87 was inferred because its DNA could transform strain FA19 for $\mathrm{HA}^{\mathrm{R}}$ (Sarubbi et al., 1975). All other strains listed in Table 1 were constructed by transformation as described below.

Bacterial growth conditions. Gonococci were grown as $\mathrm{P}^{+} \mathrm{Op}^{-}$ on GCB agar (Difco) containing defined supplements I and II (Shafer et al., 1984), at $37^{\circ} \mathrm{C}$ under $3.8 \%(\mathrm{v} / \mathrm{v}) \mathrm{CO}_{2}$. Liquid cultures of gonococci were grown in GCB broth containing supplements I and II and $0.043 \%(\mathrm{w} / \mathrm{v})$ sodium bicarbonate at $37^{\circ} \mathrm{C}$ with shaking. The MICs of various antimicrobial agents (listed in Table 1) were determined using twofold serial dilutions of the agent, as described previously (Sarubbi et al., 1975). E. coli XL1-Blue was grown on either LB agar (Difco) plates or in LB broth at $37^{\circ} \mathrm{C}$ in the presence or absence of $100 \mu \mathrm{g}$ ampicillin $\mathrm{ml}^{-1}$ (Sigma).

Analysis of MtrC. Whole cell lysates or membrane fractions (Clark et al., 1987) of N. gonorrboeae or E. coli were solubilized in Laemmli solubilization buffer (Laemmli, 1970), and subjected to SDS-PAGE and Western blotting as described previously (Judd et al., 1991). Amounts of total protein in membranes were determined by the method of Bradford (1976). MtrC was detected using an anti-MtrC monoclonal antibody (mAb) (Judd et al., 1991), or a polyclonal rabbit antiserum [kindly provided by S. Morse, Centers for Disease Control and Prevention (CDC), Atlanta, GA, USA]. Both the rabbit antiserum and the goat anti-rabbit IgG (Cappel Laboratories) were absorbed three times with heat-killed $E$. coli XL1-Blue containing pBluescript when Western blots of $E$. coli whole cell lysates were analysed for the production of MtrC. Additional $\mathrm{mAbs}$ were used to ensure that equal amounts of protein from various whole cell lysates or membrane fractions were applied to SDS-polyacrylamide gels. These mAbs included 2E6 (kindly provided by M. Tam, Genetic Systems, Seattle, WA, USA), which recognizes the reduction-modifiable membrane-protein (Rmp) (Swanson et al., 1982) and ML-30 (kindly provided by T. Shinnick, $\mathrm{CDC}$ ) that recognizes a $43 \mathrm{kDa}$ gonococcal protein bearing antigenic similarity to the $66 \mathrm{kDa}$ stress protein of Mycobacterium tuberculosis (DeMarco de Hormaeche et al., 1991). Proteins reactive with the $\mathrm{mAbs}$ or the polyclonal rabbit antiserum were detected with goat anti-mouse or goat anti-rabbit IgG coupled to alkaline phosphatase as described by Blake $e t$ al. (1984).

In certain experiments, proteins in whole cell lysates were separated by a two-dimensional (2-D) isoelectric focusing (IEF)SDS-PAGE system (O'Farrell et al., 1977; Dunbar et al., 1990), using the Bio-Rad Mini-PROTEAN II apparatus. IEF was performed at $700 \mathrm{~V}$ for $4 \mathrm{~h}$. The tube gels were then equilibrated with SDS-PAGE sample buffer for $20 \mathrm{~min}$ at room temperature and loaded onto $15 \%(\mathrm{w} / \mathrm{v})$ acrylamide slab gels for electrophoresis in the second dimension. Proteins were visualized by staining with Coomassie Brilliant Blue (CBB), or were transferred to nitrocellulose membranes for subsequent probing with the anti-MtrC $\mathrm{mAb}$. 
The $m$ trRCDE system of antibiotic resistance

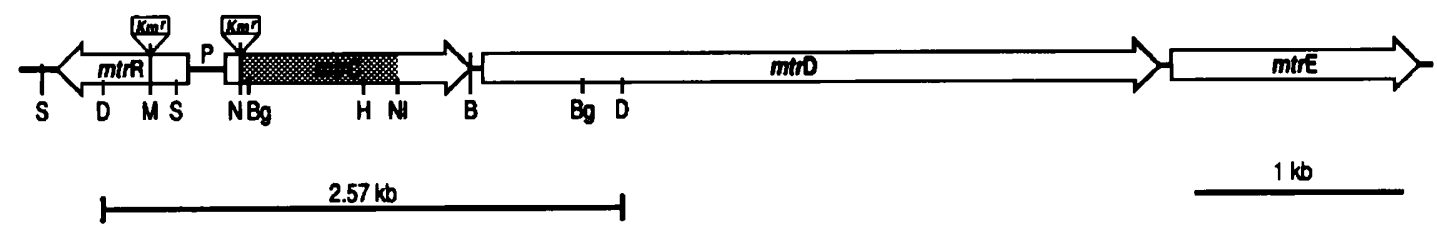

Fig. 1. Organization of the $m \operatorname{trRCDE}$ region in $N$. gonorrhoeae. The order and transcriptional orientation of the $m t r R C D E$ genes are shown. The restriction fragment in pKH9 is highlighted by the bar labelled $2.57 \mathrm{~kb}$. The sites of the $\mathrm{Km}^{\mathrm{R}}$ cassette in the mtrR gene in strain KH9, and in the mtrC gene in strains KH12 and KH13 are shown. S, Styl; D, Dral; M, Mlul; N, Notl; Bg, Bgll; NI, NlalV; H, Hincll; B, Bsp106; P, promoter region. The shaded area in mtrC signifies the Notl-NlalV fragment used to detect $m t r C$ in Southern hybridization experiments. The size of the $m$ trD gene was estimated based on results obtained from agarose gel electrophoresis of a PCR-amplified product.

Lipoproteins, including $\mathrm{MtrC}$, were labelled during growth of gonococcal strains in $5 \mathrm{ml} \mathrm{GCB}$ broth containing $10 \mu \mathrm{Ci} \mathrm{m} l^{-1}$ $\left(370 \mathrm{kBq} \mathrm{ml}^{-1}\right)\left[{ }^{3} \mathrm{H}\right]$ palmitate (Chen et al., 1985). Whole cell lysates of labelled gonococci (strains KH8 and KH13) were subjected to SDS-PAGE and autofluorography. The dried SDS-polyacrylamide gel was exposed to Kodak X-OMAT $\mathrm{X}$-ray film for two weeks at $-70^{\circ} \mathrm{C}$ prior to development.

Cloning of mtrCDE. A $\lambda$ ZAPII library of DraI-digested FA19 chromosomal DNA fragments with attached EcoRI linkers (Cornelissen et al., 1993) was kindly provided by C. N. Cornelissen and P. F. Sparling (University of North Carolina, Chapel Hill). This phage bank was propagated on E. coli XL1Blue in the presence of IPTG (Sigma) (Sambrook et al., 1989). Plaque lifts, representing over 30000 individual plaques, were screened with the rabbit anti-MtrC antiserum for production of $\mathrm{MtrC}$. Six immunoreactive plaques were recovered and then rescreened in the absence of IPTG. Phagemid DNA was excised (Sambrook et al., 1989) from two positive plaques obtained after this second screening, and the gonococcal insert was liberated by digestion with EcoRI. A limited restriction map of the gonococcal insert from one of the phagemid constructs ( $\mathrm{pKH}$ ) was prepared after digestion with a variety of restriction endonucleases (see Fig. 1). Defined deletions of the insertion in $\mathrm{pKH} 9$ were prepared by digesting $\mathrm{pKH} 9$ with appropriate restriction endonucleases followed by ligation (Sambrook et al., 1989). These constructs were introduced into E. coli XL1-Blue by electroporation and were analysed for production of $\mathrm{Mtr} C$ by SDS-PAGE and Western blotting. The Western blots were probed with the rabbit antiserum described above.

A DNA fragment containing the remainder of the $m \operatorname{tr} D$ gene and the $5^{\prime}$-end of the $m t r E$ gene was identified from a plasmid library of partial SauIIIA-digested chromosomal DNA prepared from strain CH95 (Pan \& Spratt, 1994), using a HindIII-DraI fragment of the $m$ trD gene from pKH9 (Fig. 1) as a probe in colony hybridizations.

Molecular analyses. Several oligonucleotide primers specific for the $m t r$ region and two primers that anneal to the pBluescript vector (CM6, 5'-TCACACAGGAAACAGCTATGACC-3' and CM7, 5'-CCAGTCACGACGT'TGTAAAACG-3') were prepared by L. Jones (Microchemical Facility, Emory University) and used in sequencing the gonococcal DNA insert in pKH9 (or its subclones); additional primers were prepared as necessary to complete the sequencing. Primers were labelled with $\left[\gamma^{32} \mathrm{P}\right]$ ATP (NEN DuPont) and both strands of the original insert were sequenced in their entirety using the Ampli'Taq cycle sequencing kit (Perkin Elmer) as recommended by the manufacturer. The DNA sequence of the ends of the insert containing the partial $m t r D$ and $m t r E$ genes was determined using both universal and reverse M13/pUC primers. PCR products were sequenced by the cycle sequencing procedure. Typically, two different PCR reactions were analysed to account for possible errors due to Taq polymerase. Dried gels were exposed to Kodak XAR film at room temperature and developed after 24-96 h. Nucleotide and amino acid sequence analysis was performed using DNAStar. Predicted amino acid homologies were determined after searching the GBTRANS/Swiss-Prot/EMBL databases using the DNAStar Proscan program. The nucleotide sequence for the $m \operatorname{tr} C$ gene has been deposited in GenBank under accession number U14993.

Oligonucleotide primers CEL-1 (5'-GACAATGTTCATGCGATGATAGG-3'), which anneals 120 nucleotides downstream from the translational stop codon for $m t r R$, and KH9\#3 (5'GACGACAGTGCCAATGCAACG- $3^{\prime}$ ), which anneals 24 nucleotides downstream of the $m \operatorname{tr} C$ translational start codon, were used to amplify a $1087 \mathrm{bp}$ product containing the $m \operatorname{tr} \mathrm{R}$ region from chromosomal DNA prepared from strains FA19, FA171, BR87 and KH8 and their respective $\mathrm{HA}^{\mathrm{R}}$ transformants. Conditions of PCR reactions were essentially as described previously (McAllister \& Stephens, 1993). Amplification was carried out for 30 cycles using a two-step programme consisting of a 1 min denaturation at $95^{\circ} \mathrm{C}$ followed by a $1 \mathrm{~min}$ anneal and extension at $60^{\circ} \mathrm{C}$ using a Perkin Elmer 480 thermal cycler.

Primer extensions were performed with $40 \mu \mathrm{g}$ total RNA, prepared by the method of Baker \& Yanofsky (1968), employing oligonucleotides that annealed within 100 bases of the $5^{\prime}$-end of the transcripts and the AMV Reverse Transcriptase Primer Extension System from Promega. To determine transcriptional start points, the extension products were analysed on a $6 \%$ sequencing gel beside reference sequencing reactions derived from the same oligonucleotides used for primer extension analysis.

Transformation experiments. Gonococcal chromosomal DNA was extracted from $16 \mathrm{~h}$ agar-grown cultures as described by McAllister \& Stephens (1993). For transformation, PCRamplified $m t r R$ genes were purified by agarose gel electrophoresis, electroeluted into TBE buffer, ethanol precipitated and dissolved in TE buffer. Recipient FA19 $\mathrm{P}^{+}$organisms were scraped from GCB agar plates after 16-18 h growth and resuspended in GC broth containing defined supplements I and II, $2 \mathrm{mM} \mathrm{MgCl}$ and $0.043 \%(\mathrm{w} / \mathrm{v}$ ) sodium bicarbonate to a density of approximately $1 \times 10^{8}$ c.f.u. $\mathrm{ml}^{-1}$. Gonococci were incubated with $0.5 \mu \mathrm{g} \mathrm{DNA} \mathrm{ml}{ }^{-1}$ for $30 \mathrm{~min}$ at $37^{\circ} \mathrm{C}$ prior to plating onto GCB agar plates. After $4-6 \mathrm{~h}$ incubation at $37^{\circ} \mathrm{C}$, agar overlays containing appropriate antibiotics were added to the plates with continued incubation at $37^{\circ} \mathrm{C}$, under $3.8 \%(\mathrm{v} / \mathrm{v})$ $\mathrm{CO}_{2}$ for $48 \mathrm{~h}$.

To introduce cloned $m$ trR fragments into strain FA19, replicative-form DNA from M13mp18 clones containing either the $750 \mathrm{bp} m$ trR -95 gene fragment from strain $\mathrm{CH} 95$ or 
$m t r R:: \mathrm{Km}^{\mathbf{R}}$ (Pan \& Spratt, 1994) was used in transformation as described above to construct strain KH8 (as FA19 but $m$ trR-95) and strain $\mathrm{KH} 9$ (as FA19 but $m$ trR : $: \mathrm{Km}^{\mathrm{R}}$ ). Strain KH11 was constructed using a plasmid that contains a deletion of the $m t r R$ gene from the StyI site located 21 codons into the start of the $m t r R$-coding region to the $S t y \mathrm{I}$ site located six nucleotides past the translational stop codon (Fig. 1). Strains KH12 and KH13 are transformants of strains FA19 and $\mathrm{KH} 8$ respectively that contain a $1.3 \mathrm{~kb} \mathrm{Km}^{\mathrm{R}}$ cassette (Stoker et al., 1982) in the $5^{\prime}$ proximal NotI site of the $m t r C$ gene. Strains KH15, KH16, and $\mathrm{KH} 17$ were constructed by transformation using PCR-amplified products of $1087 \mathrm{bp}$, corresponding to the $m$ tr $\mathrm{R}$ region from strains FA171, BR87, and $\mathrm{KH} 8$, respectively. $\mathrm{Km}^{\mathrm{R}}$ transformants were selected using $50 \mu \mathrm{g}$ kanamycin $\mathrm{ml}^{-1}$, while Ery ${ }^{\mathrm{R}}$ transformants were selected using $0.5 \mu \mathrm{g}$ erythromycin $\mathrm{ml}^{-1}$.

\section{RESULTS}

\section{Characterization of the $\mathrm{mtrC}$-encoded lipoprotein in gonococci}

In a previous report the complete amino acid sequence for the MtrR regulatory protein of $N$. gonorrboeae was presented (Pan \& Spratt, 1994). Upstream and divergently transcribed from the mtrR gene, an incomplete open reading frame (ORF) was identified and termed $m \operatorname{tr} C$. The partial amino acid sequence of $m \operatorname{tr} C$ appeared to encode a membrane lipoprotein similar to the AcrA and EnvC lipoproteins of $E$. coli. Analysis of the sequence upstream of the acr $A$ and $e n \nu C$ genes of $E$. coli revealed the presence of the $a r r R$ and $e n v \mathrm{R}$ genes, respectively.

We have cloned a complete $m t r C$ gene on a 2578 bp DNA fragment, derived from strain FA19, in pKH9 (Fig. 1). pKH9 directed the synthesis in E. coli XL1-Blue of a $40 \mathrm{kDa}$ protein (Fig. 2) that reacted in Western blots with the rabbit antiserum against the previously termed Mtrassociated lipoprotein (Chen $e t$ al., 1985). Deletions at the $3^{\prime}$-end of the cloned fragment up to the Bsp106 site (Fig. 1) had no effect on synthesis of this protein when such subclones of pKH9 were introduced into $E$. coli (data not presented). However, a deletion variant of $\mathrm{pKH} 9$ that lacked the $5^{\prime}$-end of the fragment up to the NotI site (Fig. 1) permitted the synthesis of this protein only when IPTG was added to the culture (data not presented), suggesting that a functioning promoter region for $m+r C$ in E. coli was upstream of the NotI site. Hence, these studies permitted the localization of the $m \operatorname{tr} C$ gene to the region shown in Fig. 1. When a $980 \mathrm{bp} \mathrm{NotI-NlaIV} \mathrm{fragment} \mathrm{(Fig.} \mathrm{1,}$ shaded area) was used to probe Southern blots of DraIdigested FA19 chromosomal DNA, it was determined that gonococci possess a single copy of the $m \operatorname{tr} C$ gene (data not presented).

The nucleotide sequence of the insert in $\mathrm{pKH} 9$ confirmed the presence of a complete $m \operatorname{tr} C$ gene. Translation of the $m \operatorname{tr} C$ gene revealed a 412 amino acid lipoprotein having a molecular mass of $42777 \mathrm{Da}$ (Fig. 3) with a bacterial signal peptidase II consensus site (LSSC) (von Heijne, 1989) located at positions 22-25. Acylation of the Cys-25 residue by a fatty acid moiety occurs prior to cleavage of the signal peptide from the mature lipoprotein. Indeed, insertional-inactivation of the $m \operatorname{tr} C$ gene in gonococci,

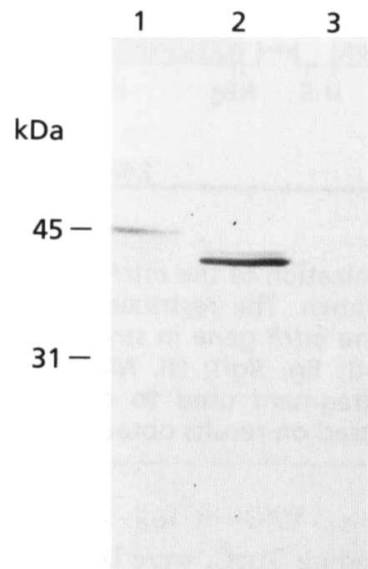

Fig. 2. Production of MtrC from $N$. gonorrhoeae in $E$. coli. Western blot analysis demonstrating expression of MtrC in $E$. coli XL1-Blue(pKH9) and $N$. gonorrhoeae strain FA19. Solubilized, whole-cell lysates from FA19 (lane 1), XL1Blue(pKH9) (lane 2) and the control XL1-Blue(pBluescript) (lane 3) were separated by SDS-PAGE and the blot was probed with a $1: 10000$ dilution of the polyclonal rabbit antiserum. The faint band above the predominant band is likely to be $\mathrm{MtrC}$ with an uncleaved leader peptide. Approximate molecular masses, which were determined using Bio-Rad low range standards, are indicated on the left in $\mathrm{kDa}$.

due to the presence of a $\mathrm{Km}^{\mathrm{R}}$ cassette in the NotI site located at the $5^{\prime}$-end of the gene (Fig. 1), resulted in the loss of a comparatively minor lipoprotein that in the parental strain migrated with an apparent molecular mass of $47 \mathrm{kDa}$ (data not presented). Removal of the leader sequence by signal peptidase II would result in the unmodified MtrC protein having a molecular mass of $40437 \mathrm{Da}$ and a $\mathrm{pI}$ of 8.01 ; the calculated $\mathrm{pI}$ for $\mathrm{MtrC}$ was consistent with its electrophoretic mobility in IEF gels (see below). Hydropathy analysis of $\mathrm{MtrC}$ failed to reveal, outside of the signal sequence, extended regions of significant hydrophobicity expected for a typical membrane protein (data not presented). This characteristic is not unusual since MtrC-homologues (see below) often display a similar property (Saier et al., 1994).

At the amino acid level, the $\mathrm{MtrC}$ lipoprotein from strain FA19 was $99 \cdot 24 \%$ identical to the partial (263 amino acids) sequence reported for the MtrC protein of strain CH95 (Pan \& Spratt, 1994). Using the DNAStar Proscan program to search the GBTRANS/Swiss-Prot/EMBL databases, the similarity of MtrC with AcrA, EnvC and MexA was confirmed (Fig. 3). MexA (Poole et al., 1993b) has been reported to display similarity with certain bacterial efflux and transporter proteins, which belong to the membrane fusion protein (MFP) family described by Saier et al. (1994). These proteins include CzcB (Nies et al., 1989), EmrA (Lomovskaya \& Lewis, 1992), HlyD (Hess et al., 1986), and LktD (Guthmiller et al., 1990). These MFPs apparently have the same general topology and structure (Saier et al., 1994), but display considerable sequence differences. Alignment of the $m \operatorname{tr} C$ sequence 


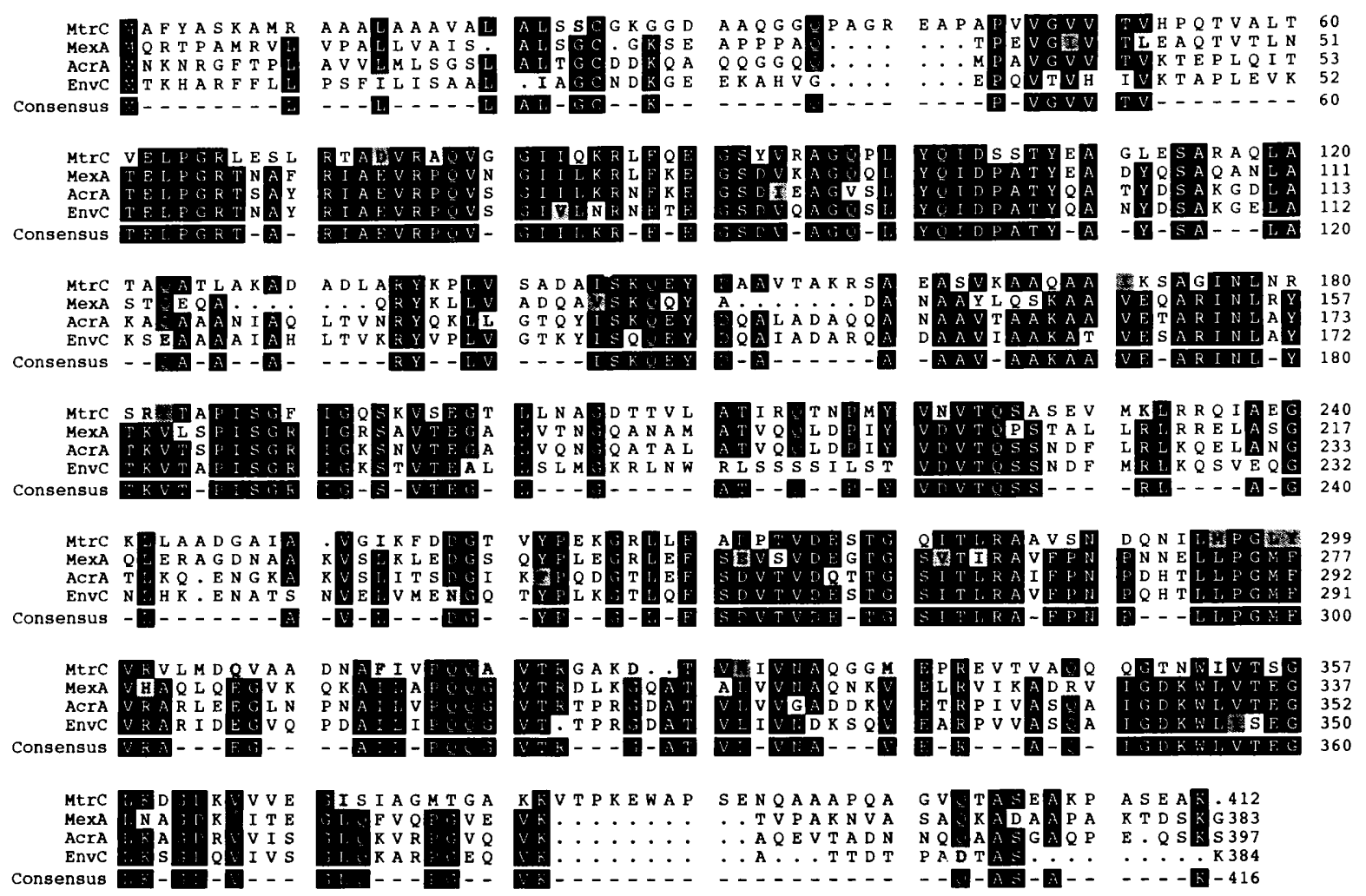

Fig. 3. Complete amino acid sequence for the $N$. gonorrhoeae MtrC lipoprotein deduced from the nucleotide sequence of the $m t r C$ gene from strain FA19, and its alignment with the AcrA, EnvC and MexA lipoproteins. The amino acids are denoted by the single-letter amino acid code. Conserved amino acid substitutions are shown in lightly shaded boxes. A proposed consensus sequence in which at least three out of four amino acids are identical is shown.

with $\mathrm{CzcB}$, HlyD, LktD and EmrA revealed (data not presented) regions of identity, which consisted of overlaps of 49 amino acids (EmrA) to 324 amino acids (CzcB). Over the regions of overlap, $\mathrm{MtrC}$ was $27 \cdot 8 \%$ identical to $\mathrm{CzcB}, 22 \cdot 3 \%$ identical to HlyD, $17 \cdot 9 \%$ identical to $\mathrm{LktD}$, and $24.5 \%$ identical to EmrA.

\section{Organization and importance of the $m$ trRCDE region in gonococci}

The DNA sequence upstream from the $m t r C$ gene in pKH9 contained the incomplete mtrR ORF which is transcribed divergently from $m \operatorname{tr} C$ (Pan \& Spratt, 1994). It also revealed the presence of a $13 \mathrm{bp}$ inverted repeat sequence (Fig. 4) positioned between the -10 and -35 regions of the $m t r R$ promoter. A consensus -10 DNA sequence for the $m \operatorname{tr} C$ promoter was identified (Fig. 4), but only a weak -35 DNA sequence ( $5^{\prime}$-TTATCC-3'), beginning within the $13 \mathrm{bp}$ inverted repeat, could be identified. A comparison of this sequence with the corresponding DNA sequence from strain $\mathrm{CH} 95$ revealed that strain $\mathrm{CH} 95$ had a single bp (T/A) deletion in the $13 \mathrm{bp}$ inverted repeat. In subsequent experiments (see below), it was determined that the single bp deletion in the $13 \mathrm{bp}$ inverted repeat was important in determining high level $\mathrm{HA}^{\mathbf{R}}$ in gonococci.
The DNA sequence $12 \mathrm{bp}$ downstream from the translational stop codon of the $m \operatorname{tr} C$ gene in pKH9 revealed the start of a third ORF, mtrD (Fig. 1). This incomplete ORF encoded 243 amino acids of a protein, MtrD, with similarity to the AcrE, EnvD and MexB proteins (Fig. 5) that have reported molecular masses of $110 \mathrm{kDa}$. MFPs, such as MtrC, are thought to act with certain transporter proteins (e.g. EnvC with EnvD), which belong to the resistance/nodulation/cell division (RND) family, to promote energy-dependent efflux of their substrates across bacterial membranes. Accordingly, MtrD is predicted to belong to the RND family of proteins. In order to obtain the remainder of the $m \operatorname{tr} D$ gene, a DNA fragment from the end of the incomplete $m \operatorname{tr} D$ gene in pKH9 was used as a probe to identify plasmids with overlapping fragments from a library of partial SauIIIAdigested DNA of strain CH95 (Pan \& Spratt, 1994). A plasmid was isolated that contained the remainder of an $m t r D$ gene including the putative translational stop codon (data not presented). The size of the complete mtr $D$ gene in strains FA19 and $\mathrm{CH} 95$ was estimated by PCR analysis and oligonucleotide primers that annealed to the $5^{\prime}$-ends of the coding and non-coding strands. The complete $m \operatorname{tr} D$ gene was estimated to be $3 \mathrm{~kb}$, a value consistent with an MtrD protein having a molecular mass of nearly $110 \mathrm{kDa}$ (data not presented). 


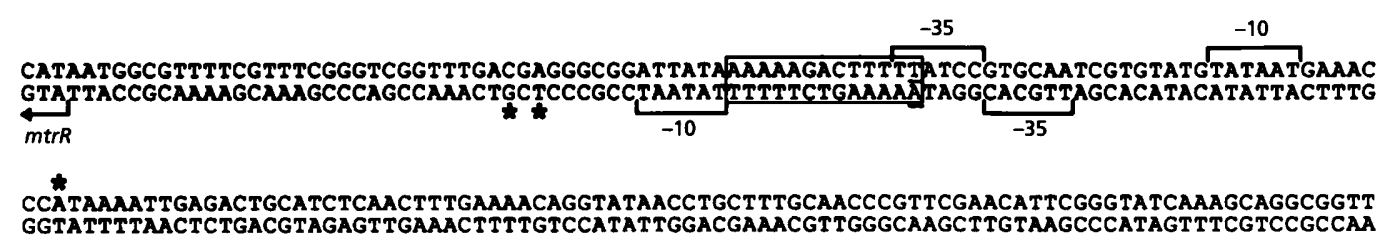

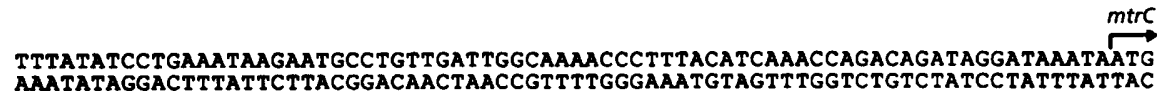

Fig. 4. Presence of a $13 \mathrm{bp}$ inverted repeat between the $m t r R$ and $m t r C$ genes and identification of their promoter regions. The $13 \mathrm{bp}$ inverted repeat nucleotide sequence between the divergent translational start codons for the $m$ trR and $m$ trC genes in $N$. gonorrhoeae strain FA19 is shown in the boxed area. The site of the single bp deletion in strains CH95 and FA171 and transformants (KH8, KH15 and KH17) of strain FA19 obtained with DNA from strains CH95 or FA171 is underlined. The transcriptional start points (*) of the $m t r R$ and $m t r C$ genes were mapped by primer extension and the -10 and -35 sequences were deduced as shown; two start points of transcription for the $m$ trR gene were reproducibly observed.

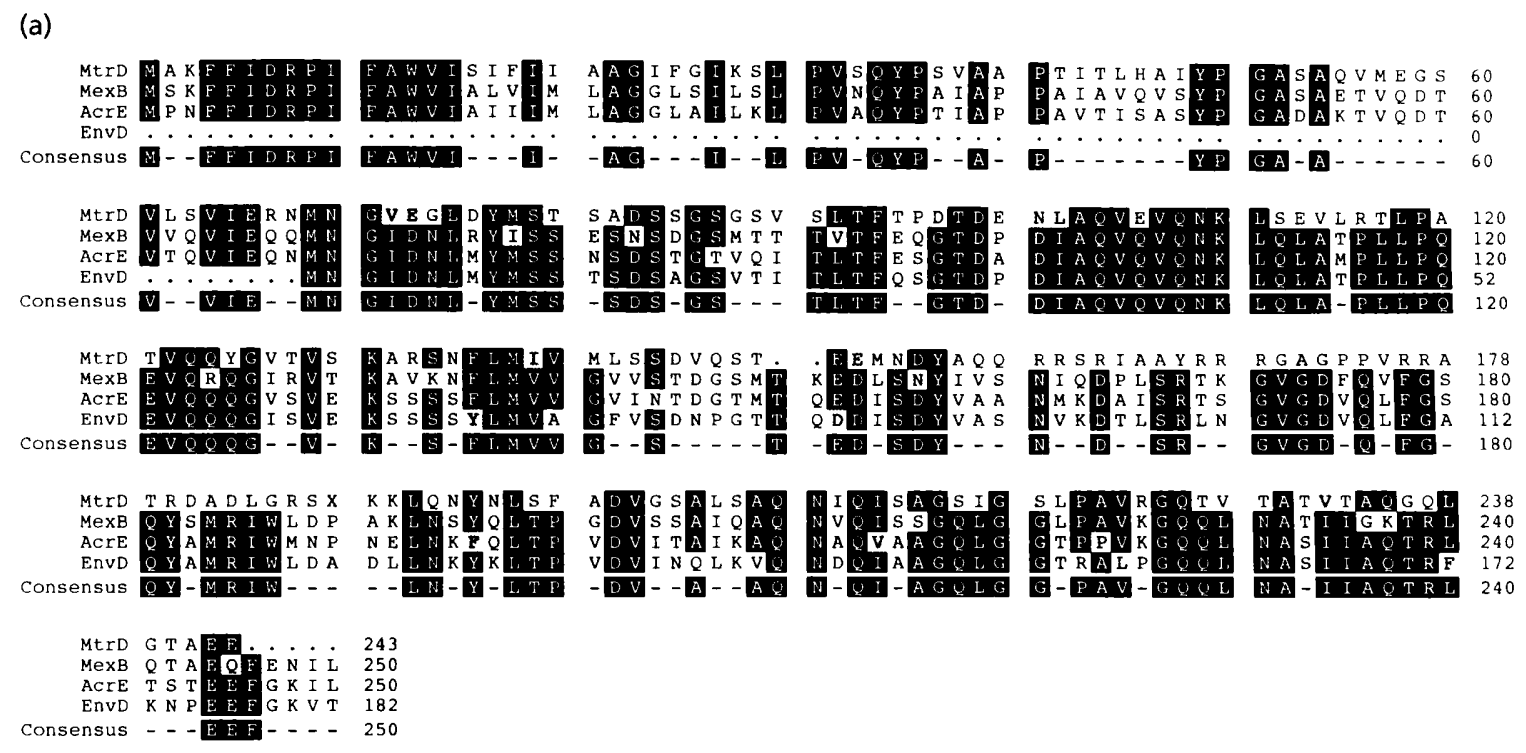

(b)

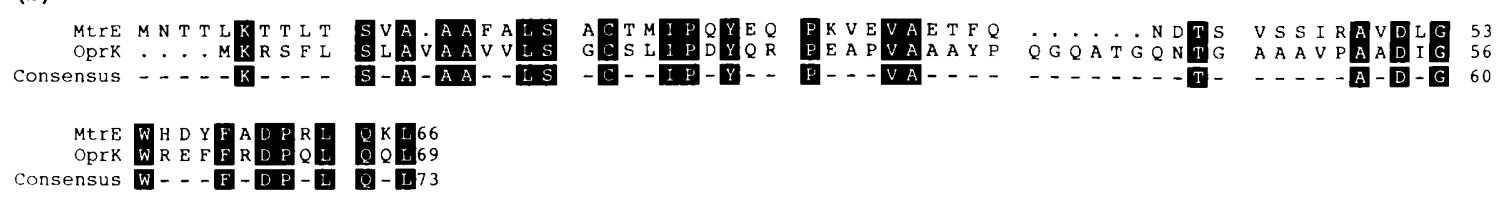

Fig. 5. Alignment of partial MtrD and MtrE sequences with similar bacterial proteins. (a) $\mathrm{N}$-terminal amino acid sequence for MtrD and its alignment with the MexB, AcrE and EnvD proteins, with a proposed consensus sequence where at least 3 out of $\mathbf{4}$ amino acids are identical. (b) N-terminal amino acid sequence for the putative MtrE lipoprotein, alignment with the OprK lipoprotein from $P$. aeruginosa, and a proposed consensus sequence.

The plasmid containing the partial mtrD gene also contained the start of the ORF that would encode a putative lipoprotein that was homologous $(36.2 \%$ identical over 69 amino acids) to OprK of P. aeruginosa (Fig. 5). The incomplete $m$ tr $E$ gene was located 36 bp downstream from the translational stop codon of the $m \operatorname{tr} D$ gene. Since consensus -10 and -35 regions could not be detected between the $m \operatorname{tr} C$ and $m \operatorname{tr} D$ genes or the $m \operatorname{tr} D$ and $m \operatorname{tr} E$ genes, it is likely that these three genes represent a single transcriptional unit, a property similar to the acr $A E(\mathrm{Ma}$ et al., 1993) and envCD (Klein et al., 1991) operons in $E$. coli and mex ABoprK in $P$. aeruginosa (Poole et al., 1993a). Further support for the hypothesis that $m \operatorname{tr} C D E$ represents a single transcriptional unit is the lack of the DNA 
Table 1. Susceptibility of gonococcal strains to antimicrobial agents, and levels of MtrC

\begin{tabular}{|c|c|c|c|c|c|c|}
\hline \multirow[t]{2}{*}{ Strain } & \multicolumn{5}{|c|}{ Minimum inhibitory concentrations $\left(\mu \mathrm{g} \mathrm{ml}^{-1}\right)$ of*: } & \multirow[t]{2}{*}{$\mathrm{MtrC} \dagger$} \\
\hline & Ery & Rif & Pen & $\mathbf{T X}$ & CV & \\
\hline FA19 (wild-type) & $0 \cdot 25$ & 0.06 & 0.008 & 125 & $2 \cdot 5$ & + \\
\hline FA171 (mtrR-171) & $2 \cdot 0$ & $0 \cdot 25$ & 0.032 & $>16000$ & 10 & ++++ \\
\hline $\mathrm{KH} 8(m \operatorname{trR}-95)$ & $2 \cdot 0$ & $0 \cdot 25$ & 0.032 & $>16000$ & 10 & ++++ \\
\hline $\mathrm{KH} 9\left(m t r R:: \mathrm{Km}^{\mathbf{R}}\right)$ & $1 \cdot 0$ & $0 \cdot 25$ & 0.016 & 1000 & 5 & +++ \\
\hline $\mathrm{KH} 11(\Delta m t r \mathrm{R})$ & $1 \cdot 0$ & $0 \cdot 25$ & 0.016 & 1000 & 5 & +++ \\
\hline $\mathrm{KH} 12\left(m \operatorname{tr} C:: \mathrm{Km}^{\mathrm{R}}\right)$ & $0 \cdot 06$ & $0 \cdot 015$ & 0.008 & 31 & $1 \cdot 25$ & - \\
\hline $\mathrm{KH} 13\left(m t r C:: \mathrm{Km}^{\mathrm{R}} m \operatorname{tr} \mathrm{R}-95\right)$ & 0.06 & 0.015 & 0.008 & 31 & $1 \cdot 25$ & - \\
\hline $\mathrm{KH} 15(m t r R-171) \ddagger$ & $2 \cdot 0$ & ND & ND & $>16000$ & 10 & ++++ \\
\hline $\mathrm{KH} 16(m+r \mathrm{R}-87) \mathrm{S}$ & $1 \cdot 0$ & ND & ND & 1000 & 5 & +++ \\
\hline $\mathrm{KH} 17(m \operatorname{tr} \mathrm{R}-95) \|$ & $2 \cdot 0$ & ND & ND & $>16000$ & 10 & ++++ \\
\hline $\mathrm{KH} 20\left(m \operatorname{trR}-171:: \mathrm{Km}^{\mathrm{R}}\right)$ & $2 \cdot 0$ & ND & ND & $>16000$ & 10 & ND \\
\hline $\mathrm{BR} 87$ (mtrR-87, env-2) & $0 \cdot 06$ & $0 \cdot 03$ & 0.069 & $62 \cdot 5$ & $1 \cdot 25$ & + \\
\hline
\end{tabular}

ND, Not done.

* Ery, erythromycin; Rif, rifampin; Pen, penicillin; TX, Triton X-100; CV, crystal violet.

fIntensity of anti-MtrC mAb reactivity in Western blots with all values compared to that of the level of MtrC in strain FA19.

$\ddagger$ Obtained with the mtrR-171 sequence derived from PCR amplification of chromosomal DNA from strain FA171, and contains the single bp deletion in the $13 \mathrm{bp}$ inverted repeat in the $m \operatorname{tr} R / m \operatorname{tr} C$ promoter region.

\Obtained with the $m$ trR sequence derived from PCR amplification of chromosomal DNA from strain BR87.

\| Obtained with the mtrR-95 sequence derived from PCR amplification of chromosomal DNA from strain KH8.

I BR87 is derived from strain FA47 (as FA19 but env-2 str-7 penA2) and FA140 (as FA19 but penA2 mtrR-171 penB2); see Methods.

uptake sequence ( $5^{\prime}$-GCCGTCTGAA-3') between these genes, which is often part of putative transcriptional terminators (Goodman \& Scocca, 1988).

To confirm the importance of the $m \operatorname{tr} C D E$ region in determining levels of $\mathrm{HA}^{\mathrm{R}}$ in gonococci, the effect of $m t r C$-inactivation in strain FA19 was determined. For this purpose a $4.3 \mathrm{~kb}$ PvuII fragment from pKH10 containing $m \operatorname{tr} C:: \mathrm{Km}^{\mathrm{R}}$ was used to transform strain FA19 for $\mathrm{Km}^{\mathrm{R}}$. Southern hybridization experiments (data not presented) demonstrated that the single copy of the $m \operatorname{tr} C$ gene possessed by transformant strain $\mathrm{KH} 12$ had been inactivated by the $1.3 \mathrm{~kb} \mathrm{Km}^{\mathrm{R}}$ cassette. Compared to parental strain FA19, strain KH12 was found to be hypersusceptible to a panel of HAs (Table 1). To determine whether inactivation of the $m \operatorname{tr} C$ gene possessed by a highly HA-resistant strain would also result in hypersusceptibility to $\mathrm{HAs}$, the $m \operatorname{tr} C$ gene of strain $\mathrm{KH} 8$ (as FA19 but $m$ trR-95; see Table 1 ) was inactivated by insertion of the $1.3 \mathrm{~kb} \mathrm{Km}^{\mathrm{R}}$ cassette at the NotI site as described in Methods. Compared to parental strain KH8, a representative $\mathrm{Km}^{\mathrm{R}}$ transformant, strain $\mathrm{KH} 13$, was found to be hypersusceptible to HAs and penicillin (Table 1), but was equally sensitive to the hydrophilic antibiotic streptomycin (MIC equal to $40 \mu \mathrm{g}$ streptomycin ml $\mathrm{m}^{-1}$ ). These results confirmed the importance of the mtrCDE region in determining $\mathrm{HA}^{\mathrm{R}}$ in gonococci.

Taken together, the organization of the $m \operatorname{tr} R C D E$ region and its contribution to $\mathrm{HA}^{\mathrm{R}}$ in gonococci represents a combination of features displayed by the acrR $A E$ and env RCD operons in E. coli and the mex $A B o p r K$ system in $P$. aeruginosa. $N$. gonorrboeae appears to have combined features of both systems, a regulatory gene, $m t r R$, similar to $a c r R$ and $e n v \mathrm{R}$ of $E$. coli and three genes, mtrCDE, encoding proteins similar to the mexABoprK-encoded membrane proteins possessed by $P$. aeruginosa.

\section{Mutations in the mtrR gene enhance levels of MtrC and $H^{R}$}

Both missense and null mutations in the mtrR gene are known to enhance levels of gonococcal $\mathrm{HA}^{\mathrm{R}}$ ( $\operatorname{Pan} \&$ Spratt, 1994). Earlier, an undefined mutation in the $m t r R$ gene possessed by $\mathrm{HA}^{\mathbf{R}}$ transformants of strain FA19 was correlated with increased production of the membrane lipoprotein (Chen et al., 1985), now known to be MtrC. In order to directly test the effects of mutations in the $m t r R$ gene on levels of $\mathrm{MtrC}$, the level of MtrC in transformant strains KH8 (mtrR-95), KH9 $\left(m t r R:: \mathrm{Km}^{\mathbf{R}}\right)$ and $\mathrm{KH} 11$ $(\Delta m t r R)$, was examined and compared to that in parental strain FA19. Strain $\mathrm{KH} 8$ exhibits high level $\mathrm{HA}^{\mathrm{R}}$ (Table 1) due to the $m$ trR-95 gene from strain $\mathrm{CH} 95$ (Pan \& Spratt, 1994). Both strains KH9 and KH11 exhibited increased $\mathrm{HA}^{\mathrm{R}}$ but the level of resistance was not as great as that seen with strain $\mathrm{KH} 8$ (Table 1). A Western blot of total membrane protein from strains FA19, KH8, KH9, and $\mathrm{KH} 11$ probed with the anti-MtrC mAb showed that the level of $\mathrm{MtrC}$ was enhanced in all three of the 


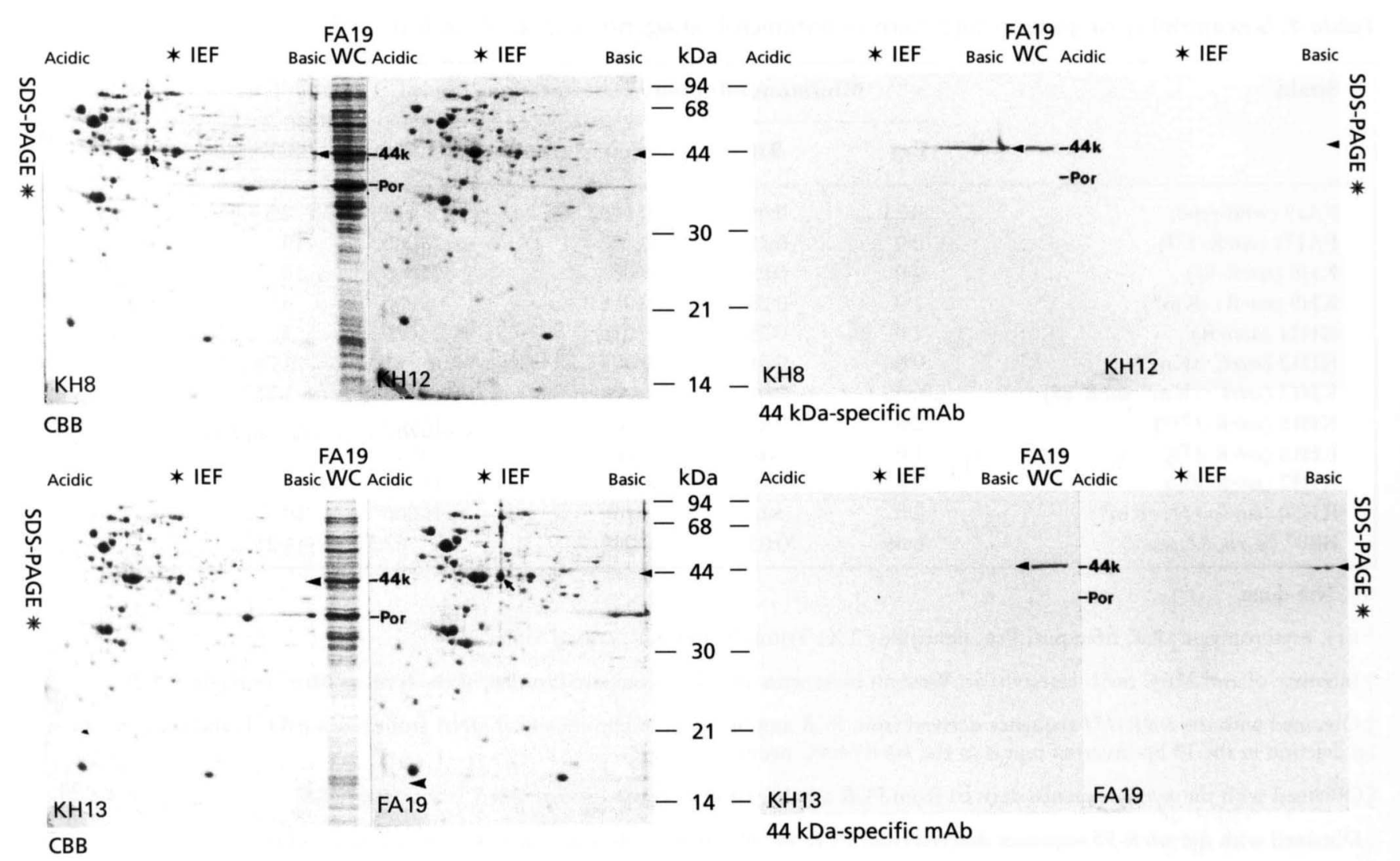

Fig. 6. 2-D IEF-SDS-PAGE and Western blot analysis of gonococcal transformant strains. Whole-cell lysates (WC) from strains FA19, KH8, KH12 and KH13 were subjected to IEF and then SDS-PAGE. Proteins were either visualized by CBBstaining (left panel) or transferred to nylon membranes and probed with the anti-MtrC mAb (labelled as $44 \mathrm{kDa}$-specific $\mathrm{mAb}$ in the right panel). WC of FA19 were also run, without prior IEF, in the SDS-polyacrylamide gel to determine electrophoretic mobility of proteins, and reactivity in Western blots with the anti-MtrC mAb. Molecular mass markers in kDa are shown between the CBB-stained gels and Western blots. The electrophoretic mobilities of the gonococcal porin protein (Por) and the $44 \mathrm{kDa}$ protein are identified. The relative migration of the MtrC protein in the 2-D gels is marked with an arrowhead $(<)$. The arrow in the CBB-stained gels indicates the acidic $44 \mathrm{kDa}$ protein that is present in FA19 and $\mathrm{KH} 8$, but absent in $\mathrm{KH} 12$ and $\mathrm{KH} 13$. The electrophoretic position of the $44 \mathrm{kDa}$ proteins that react with the anti-MtrC $\mathrm{mAb}$ is shown $(<)$.

transformants, above that observed in strain FA19, but the effect was greatest in strain KH8 (Table 1).

Since the MtrC-homologues in E. coli (AcrA and EnvC) and $P$. aeruginosa (MexA) are thought to be minor proteins we used 2-D IEF-SDS-PAGE coupled with Western blotting or CBB-staining to more precisely compare levels of MtrC in strains FA19 and $\mathrm{KH} 8$, and to ascertain whether the level of other proteins was changed due to acquisition of the $m t r R-95$ allele. $\mathrm{MtrC}$ was localized in the Western blots of these 2-D electropherograms with the anti-MtrC $m A b$. The anti-MtrC $m A b$ weakly reacted with two relatively basic proteins at $44 \mathrm{kDa}$ in the FA19 whole cell lysate (Fig. 6). The migration of $\mathrm{MtrC}$ in the IEF gel, well toward the basic region of the IEF separation, was consistent with a sequence-based predicted $\mathrm{pI}$ of 8.01 . Importantly, the $\mathrm{mAb}$ reaction was intensified and more diffuse in the whole cell lysate of strain KH8 (mtrR-95), ranging in pI from $7 \cdot 0$ to $8 \cdot 0$. This elongation was probably due to both overproduction of
MtrC and secondary components, such as fatty acid acylation of the mature MtrC protein. Analysis of the CBB-stained 2-D electropherograms revealed that a basic protein, which migrated similarly to the $\mathrm{mAb}$-reactive region, was more intensely stained in the KH8 protein sample (see < in the CBB-stained gels) than that seen with the FA19 protein sample, further indicating that the level of $\mathrm{MtrC}$ was increased in strain $\mathrm{KH} 8$ due to the presence of $m$ trR-95. These results also indicated that like EnvC (Klein et al., 1991) and AcrA (Ma et al., 1993) in E. coli, $\mathrm{MtrC}$ is a relatively minor protein.

In order to confirm that the mAb-reactive protein correlated with the CBB-staining proteins in strains FA19 and $\mathrm{KH} 8$, whole cell lysates from strains $\mathrm{KH} 12$ and $\mathrm{KH} 13$ (as $\mathrm{KH} 8$ but $m t r C:: \mathrm{Km}^{\mathrm{R}}$ ) were separated by 2-D IEF-SDS-PAGE. These $\mathrm{mAb}$ reactions were not observed with either the KH12 or KH13 samples, confirming that insertional-inactivation of $m t r C$ resulted in loss of MtrC. However, the CBB-stained 2-D electro- 


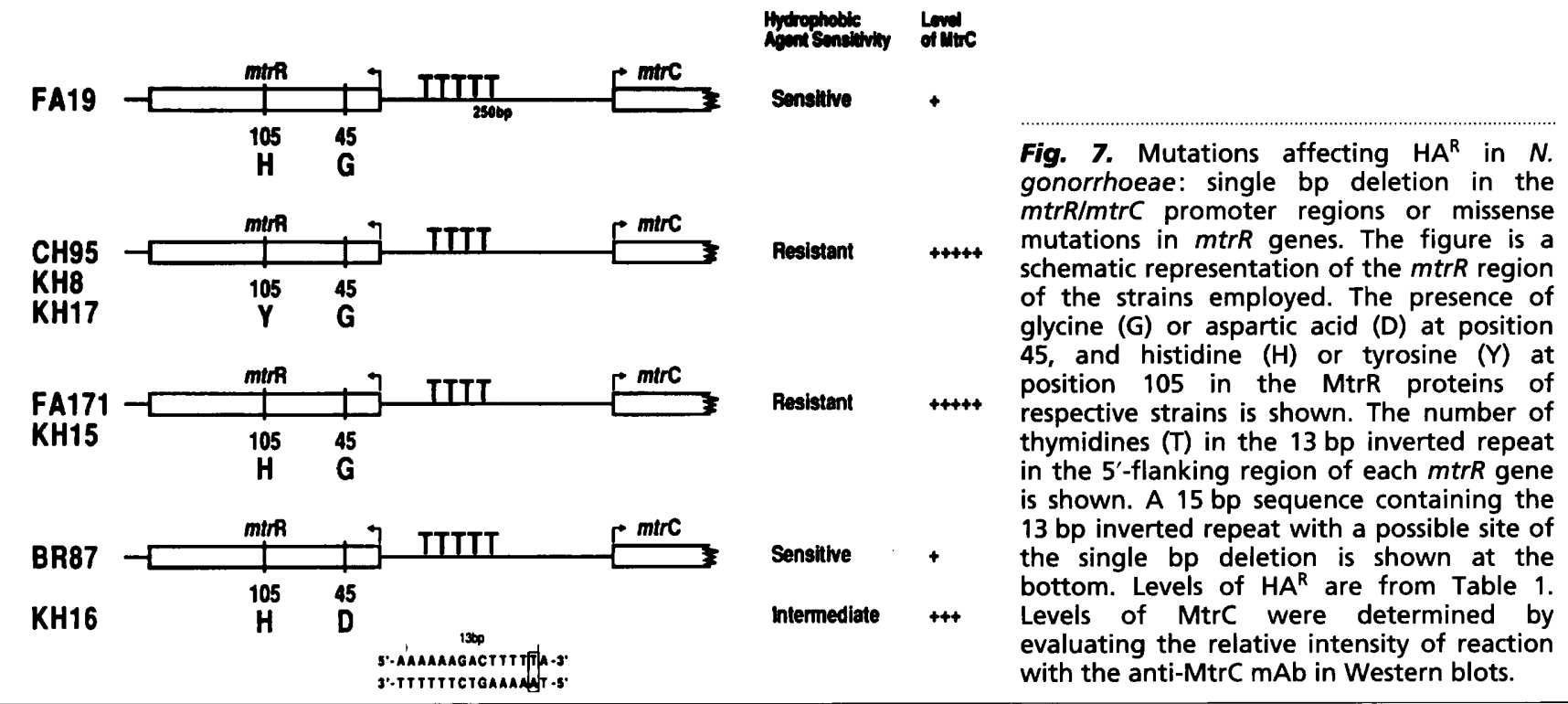

pherograms also revealed a major difference in the $44 \mathrm{kDa}$ range between strains FA19 and KH8 compared to their respective $m \operatorname{tr} C:: \mathrm{Km}^{\mathbf{R}}$ transformant strains, $\mathrm{KH} 12$ and KH13. Strains KH12 and KH13 lost expression of a relatively acidic $44 \mathrm{kDa}$ protein present in the CBBstained gels of their respective parental strains, FA19 and $\mathrm{KH} 8$ (see arrows in the CBB-stained gels). The amount of this $44 \mathrm{kDa}$ protein, as judged by $\mathrm{CBB}$-staining, appeared to be similar in strains FA19 and KH8, suggesting that, unlike MtrC, its level was not regulated by $m t r R$; the characteristics of this protein are under investigation.

\section{Importance of distinct mutations in the $\boldsymbol{m t r R}$ gene in determining levels of $H A^{R}$ in gonococci}

Results from DNA sequencing of the $m t r R$ genes from strains FA171 and BR87 suggested that levels of $\mathrm{HA}^{\mathbf{R}}$ and $\mathrm{MtrC}$ can be modulated by mutations either in the $m \operatorname{tr} \mathrm{R}$ coding sequence or in a $13 \mathrm{bp}$ inverted repeat sequence that intervenes the promoters utilized by the divergent $m t r R$ and $m \operatorname{tr} C$ genes (Fig. 4). The $m t r R$-coding sequence from strains FA19 and FA171 were identical (Fig. 7), even though strain FA171 (as FA19 but mtrR-171) displays high-level $\mathrm{HA}^{\mathbf{R}}$ (Table 1). Strain FA171 differed from strain FA19 by a single bp (T/A) deletion in the $13 \mathrm{bp}$ inverted repeat sequence (Fig. 4). In contrast, strain BR87 contained a single mutation in the $m t r R$-coding sequence located at codon 45 (G $\underline{G C}$ to $G \underline{A C}$ ) resulting in a glycine $\rightarrow$ aspartic acid change. This substitution occurred in the second helical domain of the proposed helix-turn-helix motif of the MtrR protein (Pan \& Spratt, 1994).

To confirm that the missense mutation at codon 45 could result in $\mathrm{HA}^{\mathbf{R}}$ in gonococci, the $1087 \mathrm{bp}$ PCR product from strain BR87 that included the mtrR locus and the $13 \mathrm{bp}$ inverted repeat region was used to transform strain FA19 for resistance to $0.5 \mu \mathrm{g}$ erythromycin $\mathrm{ml}^{-1}$; transformants were recovered at a frequency of $4 \times 10^{-4}$ per $10^{8}$ c.f.u. per $\mu \mathrm{g}$ DNA. Representative transformants were scored for levels of resistance to the HAs crystal violet, erythromycin and Triton X-100. The transformants (e.g. strain $\mathrm{KH} 16$ ) displayed an intermediate level of resistance to HAs, which was most clearly evident with respect to Triton X-100 susceptibility (Table 1). Moreover, MtrC expression in strain KH16 did not equal the level seen with strains FA171 and KH8 although it was enhanced above that of parental strain FA19 (Fig. 7). In this respect, strain KH16 resembled strains bearing null mutations in the mtrR gene [e.g. strains KH9 and KH11 (Table 1)]. The nucleotide sequence of the $m t r R$ region from strain KH16 was determined, and the results confirmed the presence of the missense mutation at codon 45 (Fig. 7) and the 13 bp inverted repeat DNA sequence in the promoter region.

The importance of the single bp deletion in the $13 \mathrm{bp}$ inverted repeat sequence in mediating high-level $\mathrm{HA}^{\mathrm{k}}$ was confirmed by transformation. The $m t r R$ region from an $\mathrm{HA}^{\mathrm{R}}$ transformant (strain KH15) of strain FA19, which was obtained with the PCR product from strain FA171 used in the sequencing study, also displayed this single bp deletion but was otherwise identical to the $m t r R$ sequences of strains FA19 and FA171 (Fig. 7). Transformant strain KH15, like strains FA171 and KH8, displayed both high levels of $\mathrm{HA}^{\mathrm{R}}$ (Table 1) and $\mathrm{MtrC}$ (Fig. 7). Hence, the single bp deletion in the $13 \mathrm{bp}$ inverted repeat in the promoter regions of the $m t r R$ and $m \operatorname{tr} C$ genes was responsible for these phenotypes in strain FA171. The capacity of the single bp deletion to provide high-level $\mathrm{HA}^{\mathrm{R}}$ was found to be independent of the MtrR protein because transformants of strain $\mathrm{KH} 15$ (e.g. strain $\mathrm{KH} 20$; Table 1), obtained with DNA from strain $\mathrm{KH} 9$ $\left(m t r R:: \mathrm{Km}^{\mathrm{R}}\right)$, containing an insertionally inactivated $m t r R$ gene, but maintaining the single bp deletion, continued to express high levels of $\mathrm{HA}^{\mathrm{R}}$. However, from this transformation a second class of $\mathrm{Km}^{\mathbf{R}}$ transformants were recovered that displayed the intermediate $\mathrm{HA}^{\mathbf{R}}$ property of donor strain KH9. DNA sequence analysis of 
PCR products encompassing the $m$ tr $R$ promoter region from two of these transformants revealed that these transformants now contained the $13 \mathrm{bp}$ inverted sequence, indicating repair of the single bp deletion was sufficient to reduce $\mathrm{HA}^{\mathrm{R}}$.

\section{DISCUSSION}

A recent review (Nikaido, 1994) on the mechanisms by which bacteria resist multiple antimicrobial agents, including the HAs studied herein, stressed the importance of permeability and efflux systems in allowing for resistance to structurally diverse compounds. Indeed, changes in cell envelope permeability due to the $m t r$ system have been proposed to account for resistance of gonococci to structurally diverse HAs (Guymon et al., 1975). The striking amino acid homology of the MtrCDE proteins with other proteins involved in transport of toxic compounds across membranes requires that this model be re-evaluated. In this respect, expression of the mex ABoprK operon in $P$. aeruginosa has been shown to impart nonspecific resistance to a variety of antibiotics by an efflux mechanism (Poole et al., 1993b). A complex of the MexA-MexB-OprK proteins is thought to form a continuous channel from the cytoplasm through the outer membrane that facilitates transport of agents (including membrane-damaging detergents) into the extracellular fluid. For agents that damage the membrane, it is postulated that they are captured in the membrane bilayer and transported through the channel (Nikaido, 1994). Like its homologues in E. coli and $P$. aeruginosa, MtrC is clearly located in the gonococcal cell envelope, where it would be needed to participate in efflux, but appears to be bound to peptidoglycan (Hill \& Judd, 1989). This interaction with peptidoglycan perhaps explains why MtrC fails to separate in sucrose-density gradients with either the outer or the cytoplasmic membranes, but instead fractionates in the mixed-membrane region of the gradient (J. Smith \& R. C. Judd, unpublished observations). This cellular location for $\mathrm{MtrC}$ is consistent with it belonging to the MFP family of proteins (Saier et al., 1994), which are thought to cause localized fusion of the inner and outer membranes. Hence, a continuous channel, resembling the MexA-MexB-OprK complex of $P$. aeruginosa, consisting of MtrCDE may account for the capacity of gonococci to resist $\mathrm{HAs}$ that act in the cytoplasm or by damaging the membrane.

Our observations that mutations in the $m \operatorname{tr} R$ gene of $N$. gonorrboeae resulted in $\mathrm{HA}^{\mathrm{R}}$ with a concomitant increase in the level of $\mathrm{MtrC}$, while loss of $\mathrm{MtrC}$ resulted in hypersusceptibility of gonococci to structurally diverse $\mathrm{HAs}$, confirms a role for $\mathrm{MtrC}$ in resistance. Since $m \operatorname{tr} D$ and $m$ tr $E$ are in the same apparent transcriptional unit as $m \operatorname{tr} C$, mutations affecting $m t r C$ expression are likely to affect $m$ tr $D E$ expression also. This is not unexpected since a mutation in env $C$ is known to have pleiotropic effects (Klein et al., 1991; Starkova et al., 1978) that include hypersusceptibility of $E$. coli to a variety of antimicrobial agents and chain formation at high temperature, altered phospholipid composition, and loss of EnvD. Com- plementation of these phenotypes requires both env $C$ and envD gene products (Klein et al., 1991).

Our studies confirm that the $m$ tr system of $\mathrm{HA}^{\mathrm{R}}$ in gonococci can be controlled by an MtrR-dependent mechanism of regulation that can be bypassed by missense or null mutations in the $m t r R$-coding sequence; such mutations provide for an intermediate level of resistance. The MtrR protein resembles a DNA-binding protein similar to the tetracycline repressor of pSC101 (Brow et $a l .$, 1985). Interestingly, the $m$ trR gene was found ( $\operatorname{Pan} \&$ Spratt, 1994) to be homologous to previously unidentified ORFs (acrR, envR) that are upstream of the E. coli acr $A E$ and $e n v C D$ operons. Our studies with gonococci suggest that mutations in the coding sequence of these $m t r R$ homologues would enhance the resistance of $E$. coli to antimicrobial agents by increasing the level of the AcrAE and EnvCD proteins. Pan \& Spratt (1994) found that a single amino acid change at position 105 (histidine $\rightarrow$ tyrosine) in MtrR was sufficient for $\mathrm{HA}^{\mathbf{R}}$ in a transformant of strain FA19 that was constructed by transformation using the cloned mtrR-95 allele; recent studies, however, indicate that this missense mutation confers an intermediate level of $\mathrm{HA}^{\mathbf{R}}$ similar to that of strains $\mathrm{KH} 9$, KH11 and KH16 (data not presented). The mechanism by which this single amino acid substitution would change the putative regulatory property of MtrR is not clear since the substitution is downstream of the helix-turn-helix motif, which is presumed to be important in DNAbinding and/or regulatory functions exhibited by MtrR. More easily understood is the phenotypically suppressed $m$ trR mutation ( $m$ trR-87) in strain BR87 because it results in a single, but radical, amino acid change (glycine $\rightarrow$ aspartic acid) at position 45 , which is within the second helical domain of proposed helix-turn-helix motif of MtrR. This radical substitution in the second helical domain of helix-turn-helix motif may have a direct effect on DNA-binding activity because it is predicted to increase the helical characteristic of the adjacent turn region (data not presented). Thus, it is likely that mutations in the $m$ trR-coding sequence serve to reduce or otherwise inhibit repressor activity.

By themselves, mutations in the mtrR-coding sequence afford only an intermediate level of $\mathrm{HA}^{\mathrm{R}}$ when introduced into strain FA19. It is clear from our studies that high-level $\mathrm{HA}^{\mathrm{R}}$ and $\mathrm{MtrC}$ production involves a single bp deletion in the $13 \mathrm{bp}$ inverted repeat sequence that was located between the divergent $m \operatorname{tr} R$ and $m \operatorname{tr} C$ genes (Fig. 4 ). The influence of the single bp deletion was independent of the MtrR protein, since $\mathrm{HA}^{\mathbf{R}}$ was observed in strains possessing an inactivated $m$ trR gene. Moreover, since repair of this deletion, in the absence of an intact $m t r R$ gene, resulted in intermediate $H^{\mathbf{R}}$, we propose that this $13 \mathrm{bp}$ inverted repeat is a transcriptional regulatory element. It is likely that the single bp deletion in this sequence serves to up-regulate expression of the $m \operatorname{tr} C D E$ gene complex. The deletion would also shorten the distance between the -10 and -35 regions of the $m$ trR promoter, thereby reducing expression of the $m t r R$ gene. Whether this single bp deletion enhances $m \operatorname{tr} C D E$ promoter utilization by RNA polymerase or modifies 
binding of a transcriptional regulatory protein is unclear. To our knowledge this is the first description of this type of mutation affecting resistance of bacteria to structurally diverse agents, such as the HAs studied herein, and suggests a novel genetic mechanism by which bacteria modulate levels of resistance to structurally diverse agents.

\section{ACKNOWLEDGEMENTS}

We thank P. F. Sparling for providing gonococcal strains and the $\lambda$ ZAPII bank, S. Morse for the rabbit antiserum, L. Jones (Microchemical Facility, Emory University) for preparing oligonucleotides, and C. Moran and D. Stephens for reading this manuscript prior to submission. We also thank L. Pucko for preparation of the manuscript.

This work was supported by PHS grants AI-21150 (to W. M. S.), AI-21236 (to R. C. J.) and AI-00834 (to R.C. J.), funds from the VA Medical Research Service (to W.M.S.), funds from the Emory University Research Council (to W.M.S.), and University of Montana Research Grant 1117 (to R. C. J.). Work in B. Spratt's laboratory was supported by the Medical Research Council and the Wellcome Trust. W.P. acknowledges support from the Sir Run Run Shaw Scholarship Fund.

\section{REFERENCES}

Baker, R. F. \& Yanofsky, C. (1968). The periodicity of RNA polymerase initiations: a new regulatory feature of transcription. Proc Natl Acad Sci US A 60, 313-320.

Blake, M. S., Johnston, K. H., Russell-Jones, G. J. \& Gotschlich, E. C. (1984). A rapid, sensitive method for detection of alkaline phosphatase-conjugated anti-antibody on Western blots. Anal Biochem 136, 175-179.

Bradford, M. M. (1976). A rapid and sensitive method for the quantitation of microgram quantities of protein utilizing the principle of protein-dye binding. Anal Biochem 72, 248-254.

Brow, M. A. D., Pesin, R. \& Sutcliffe, J. G. (1985). The tetracycline repressor of pSC101. Mol Biol Evol 2, 1-12.

Chen, C.-Y., Parsons, C. S. \& Morse, S. A. (1985). Membrane proteolipids of Neisseria gonorrboeae. In The Patbogenic Neisseriae, pp. 360-365. Edited by G. K. Schoolnik. Washington, DC: American Society for Microbiology.

Clark, V. L., Campbell, L. A., Palermo, D. A., Evans, T. M. \& Klimpel, K. W. (1987). Induction and repression of outer membrane proteins by anaerobic growth of Neisseria gonorrboeae. Infect Immun 55, 1359-1364.

Cornelissen, C. N., Biswas, G. D., Tsai, J., Paruchuri, D. K., Thompson, S. \& Sparling, P. F. (1992). Gonococcal transferrinbinding protein 1 is required for transferrin utilization and is homologous to TonB-dependent outer membrane receptors. $J$ Bacteriol 174, 5788-5797.

DeMarco de Hormaeche, R., Mehlert, A., Young, D. B. \& de Hormaeche, C. E. (1991). Antigenic homology between the $65 \mathrm{kDa}$ heat shock protein of Mycobacterium tuberculosis, GroEL of E. coli and proteins of Neisseria gonorrboeae expressed during infection. In Neisseriae 1990, pp. 199-203. Edited by M. Achtman and others. Berlin: Walter de Gruyter.

Dunbar, B. S., Mura, H. \& Timmons, T. (1990). Protein analysis using high-resolution two dimensional polyacrylamide gel electrophoresis. Metbods Envymol 186, 441-459.

Eisenstein, B. I. \& Sparling, P. F. (1978). Mutations to increased antibiotic sensitivity in naturally-occurring gonococci. Nature 271, $242-244$.
Goodman, S. D. \& Scocca, J. J. (1988). Identification and arrangement of the DNA sequence recognized in specific transformation of Neisseria gonorrboeae. Proc Natl Acad Sci USA 85, $69: 2-6986$.

Guthmiller, J. M., Kraig, E., Cagle, M. P. \& Kolodrubetz, D. (1990). Sequence of the lktD gene from Actinobacillus actinomycetemcomitans. Nucleic Acids Res 59, 5992.

Guymon, L. F. \& Sparling, P. F. (1975). Altered crystal violet permeability and lytic behavior in antibiotic-resistant and -sensitive mutants of Neisseria gonorrboeae. J Bacteriol 124, 757-763.

Guymon, L. F., Walstad. D. L. \& Sparling, P. F. (1978). Cell envelope alterations in antibiotic-sensitive and -resistant strains of Neisseria gonorrboeae. J Bacteriol 136, 391-401.

von Heijne, G. (1989). The structure of signal peptides from bacterial lipoproteins. Protein Eng 2, 531-534.

Hess, J., Wels, W., Vogel, M. \& Goebel, W. (1986). Nucleotide sequence of a plasmid-encoded hemolysin determinant and its comparison with a chromosomal hemolysin sequence. FEMS Microbiol Lett 34, 1-11.

Hill, S. \& Judd, R. C. (1989). Identification and characterization of peptidoglycan-associated proteins in Neisseria gonorrboeae. Infect Immun 57, 3612-3618.

Innis, M. A., Tokunaga, M., Williams, M. E., Loranger, J. M., Chang, S.-Y., Chang, S. \& Wu, H. C. (1984). Nucleotide sequence of the Eschericbia coli prolipoprotein signal peptidase $(l s p)$ gene. Proc Natl Acad Sci US A 81, 3708-3712.

Judd, R. C., Strange, J. C., Pettit, R. K. \& Shafer, W. M. (1991). Identification and characterization of a conserved outer-membrane protein of Neisseria gonorrboeae. Mol Microbiol 5, 1091-1096.

Judd, R. C. \& Porcella, S. F. (1993). Isolation of the periplasm of Neisseria gonorrboeae. Mol Microbiol 10, 567-574.

Klein, J. R., Henrich, B. H. \& Plapp, R. (1991). Molecular analysis and nucleotide sequence of the envCD operon of Escherichia coli. Mol \& Gen Genet 230, 230-240.

Laemmli, U. K. (1970). Cleavage of structural proteins during the assembly of the head of bacteriophage T4. Nature 227, 680-685.

Lomovskaya, O. \& Lewis, K. (1992). Emr, an Eschericbia coli locus for multidrug resistance. Proc Natl Acad Sci USA 89, 8938-8942.

Ma, D., Cook, D. N., Alberti, M., Pon, N. G., Nikaido, H. \& Hearst, J. E. (1993). Molecular cloning and characterization of acr $A$ and acrE genes of Escherichia coli. J Bacteriol 175, 6299-6313.

McAllister, C. F. \& Stephens, D. S. (1993). Analysis in Neisseria meningitidis and other Neisseria species of genes homologous to the FKBP immunophilin family. Mol Microbiol 10, 13-24.

Maness, M. J. \& Sparling, P. F. (1973). Multiple antibiotic resistance due to a single mutation in Neisseria gonorrboeae. J Infect Dis 128, 321-330.

Morse, S. A., Lysko, P. G., McFarland, L., Knapp, J. S., Sandstrom, E., Critchlow, C. \& Holmes, K. K. (1982). Gonococcal strains from homosexual men have outer membranes with reduced permeability to hydrophobic molecules. Infect Immun 37, 432-438,

Nies, D., Nies, A., Chu, L. \& Silver, S. (1989). Expression and nucleotide sequence of a plasmid-determined divalent cation efflux system from Alcaligenes eutrophus. Proc Natl Acad Sci USA 86, 7351-7355.

Nikaido, H. (1994). Prevention of drug access to bacterial targets: permeability barriers and active efflux. Science 264, 382-388.

O'Farrell, P. Z., Goodman, H. M. \& O'Farrell, P. H. (1977). Highresolution two-dimensional electrophoresis of basic as well as acidic proteins. Cell 12, 1133-1142. 
Pan, W. \& Spratt, B. G. (1994). Regulation of the permeability of the gonococcal cell envelope by the mtr system. Mol Microbiol 11, 769-775.

Poole, K., Heinrichs, D. E. \& Neshat, S. (1993a). Cloning and sequence analysis of an EnvCD homologue in Pseudomonas aeruginosa: regulation by iron and possible involvement in the secretion of siderophore pyoverdine. Mol Microbiol 10, 529-544.

Poole, K., Krebes, K., McNally, C. \& Neshat, S. (1993b). Multiple antibiotic resistance in Pseudomonas aeruginosa: evidence for involvement of an efflux operon. $J$ Bacteriol 175, 7363-7372.

Saier, M. H., Jr, Tam, R., Reizer, A. \& Reizer, J. (1994). Two novel families of bacterial membrane proteins concerned with nodulation, cell division and transport. Mol Microbiol 11, 841-847.

Sambrook, J., Fritsch, E. F. \& Maniatis, T. (1989). Molecular Cloning: a Laboratory Manual. Cold Spring Harbor, NY : Cold Spring Harbor Laboratory.

Sarubbi, F. A., Sparling, P. F., Blackman, E. \& Lewis, E. (1975). Loss of low-level antibiotic resistance in Neisseria gonorrboeae due to env mutations. J Bacteriol 124, 750-756.

Shafer, W. M., Guymon, L. F., Lind, I. \& Sparling, P. F. (1984). Identification of an envelope mutation (env-10) resulting in increased antibiotic susceptibility and pyocin resistance in a clinical isolate of Neisseria gonorrboeae. Antimicrob Agents Chemother 25, 767-769.

Sparling, P. F., Sarubbi, F. A. \& Blackman, E. (1975). Inheritance of low-level resistance to penicillin, tetracycline, and chloramphenicol in Neisseria gonorrboeae. J Bacteriol 124, 740-749.

Sparling, P. F., Sox, T. E., Mohammed, W. \& Guymon, L. F. (1978). Antibiotic resistance in the gonococcus: diverse mechanisms of coping with a hostile environment. In Immunobiology of Neisseria gonorrboeae, pp. 44-52. Edited by G. Brooks and others. Washington, DC: American Society for Microbiology.

Starkova, Z., Thomas, P. \& Starka, J. (1978). Morphological mutants of Escherichia coli: nature of the permeability in mon and envC cells. Ann Microbiol Inst Pasteur 129, 265-284.

Stoker, N. G., Fairweather, N. F. \& Spratt, B. G. (1982). Versatile low-copy-number plasmid vectors for cloning in Escherichia coli. Gene 18, 335-341.

Swanson, J., Mayer, L. W. \& Tam, M. R. (1982). Antigenicity of Neisseria gonorrboeae outer membrane protein(s) III detected by immunoprecipitation and Western blot transfer with a monoclonal antibody. Infect Immun 38, 668-672.

Swartzman, E., Silverman, M. \& Meighen, E. A. (1992). The luxR gene product of Vibrio barveyi is a transcriptional activator of the lux promoter. $J$ Bacteriol 17, 7490-7493.

Received 28 July 1994; revised 2 November 1994; accepted 14 November 1994. 